\title{
Comparison of Surface Quality and Tool-Life of Glulam Window Elements after Planing
}

\section{Usporedba kvalitete površine i životnog vijeka alata pri blanjanju lameliranih elemenata za prozore}

\author{
Original scientific paper • Izvorni znanstveni rad \\ Received-prispjelo: 4. 7. 2017. \\ Accepted-prihvaćeno: 10. 12. 2018. \\ UDK: $630 * 823.121 ; 674.032 .475 .442$ \\ doi: $10.5552 /$ drvind.2019.1741
}

\begin{abstract}
The quality of the surface of wooden elements, that have been planed, has a crucial importance in the whole production process, since the obtained effects affect the quality of wooden surface after finishing (painting). The occurrence of defects is usually the reason for qualifying a workpiece as scrap or for requiring additional work. This paper presents the selected results of research of the effect of the cutting tool wear on the surface quality of elements after planing. Research experiments were conducted on the SCM Superset Class machine tool. Glulam elements of pine wood (Pinus sylvestris L.) were researched. The raw material samples (semi-finished products), 6 $m$ long before planing, had been machined by suppliers also by planing. These workpieces were selected according to the plant requirements, e.g. their moisture content, straightness, and other defects. This paper presents the measuring results of surface roughness and some examples of surface profiles, as well as the dependence of total length of the planed elements on the type of blade material. From an economic point of view, the results showed that the use of solid carbide blades were more cost effective.
\end{abstract}

Key words: planing process, pine wood, window frame, surface quality, 2D/3D surface texture

\begin{abstract}
SAŽETAK • Kvaliteta površine drvenih elemenata obrađenih blanjanjem ima presudnu važnost u cjelokupnome proizvodnom procesu jer kvaliteta blanjanja utječe na kvalitetu površine drva nakon završne obrade (nakon bojenja). Zbog nastalih grešaka elementi za prozore najčešće se kvalificiraju kao škart ili se moraju obaviti dodatni poslovi radi uklanjanja tih grešaka. U radu su prikazani odabrani rezultati istraživanja utjecaja zatupljenja alata na kvalitetu površine elemenata nakon blanjanja. Istraživanje je provedeno na stroju SCM Superset Class. Kao uzorci odabrani su lamelirani elementi od borovine (Pinus sylvestris L.). Uzorci lameliranih elemenata (poluproizvoda), duljine $6 \mathrm{~m}$, već su prije eksperimentalnog blanjanja kod dobavljača također obrađeni blanjanjem. Ti su elementi selektirani prema zahtjevima tehnološkog procesa, npr. prema sadržaju vode, ravnosti i postojećim greškama drva. U radu su navedeni rezultati mjerenja kvalitete površine elemenata, kao i neki primjeri profila površine te ovisnost ukupne duljine oblanjanih elemenata o vrsti materijala oštrice alata. Rezultati su pokazali da je s ekonomskog stajališta isplativija uporaba alata soštricama od tvrdog metala.
\end{abstract}

Ključne riječi: proces blanjanja, borovina, okvir prozora, kvaliteta površine, 2D/3D tekstura površine

\footnotetext{
${ }^{1}$ Authors are senior lecturer and full professor at the Gdansk University of Technology, Faculty of Mechanical Engineering, Department of Manufacturing Engineering and Automation, Gdansk, Poland. ${ }^{2}$ Author is a process engineer in Dovista Polska sp. z o.o., Wedkowy, Poland. Autori su viši predavač i redoviti profesor Tehnološkog sveučilišta u Gdansku, Strojarski fakultet, Odjel za energetske i industrijske uređaje, Gdansk, Poljska. ${ }^{2}$ Autor je procesni inženjer u tvrtki Dovista Polska sp. z o.o., Wedkowy, Poljska.
} 


\section{INTRODUCTION}

\section{UVOD}

Surface quality of solid wood products is one of the most important properties influencing further manufacturing processes such as finishing (coating) or strength of adhesive joint (Kilic et al., 2006; Aguilera and Muñoz, 2011; Ugulino and Hernández, 2016). Nevertheless, determination of surface quality in planing is a complex process depending on the heterogeneous structure of wood species (Belleville et al., 2016; Malkoçoğlu and Özdemir, 2006; Malkoçoğlu, 2007; Sofuoğlu and Kurtoğlu, 2015), kinematics of the cutting process (Hernández and Cool, 2008; Gottlöber et al., 2015), and machining conditions (Jokerst and Stewart, 1976; Malkoçoğlu, 2007; Minami and Nishio, 2015; Stewart, 1980; Ugulino and Hernández, 2016).

Machinability of species of raw and thermally treated wood has been assessed based on quality of planed surfaces.

Belleville et al. (2016) evaluated the potential of young eucalypts growing under short rotation planting conditions, as a resource for the manufacture of high quality furniture and furnishings, which were planed with tungsten carbide cutters. In this case, the number of defects on the sample was a measure of quality acceptance.

Aguilera and Muñoz (2011) stated that better surface quality could be obtained for dense Blackwood (Acacia melanoxylon), as ten point height of irregularities $R z$ (ISO) was equal to $15 \mu \mathrm{m}$, in comparison to Redwood (Sequoia sempervirens), where $R z$ (ISO) was $22 \mu \mathrm{m}$. The experiments were conducted with a tool of $\varnothing 124 \mathrm{~mm}$ in diameter, equipped with 4 knives made of high speed steel, with their geometry as follows: rake angle $25^{\circ}$ and clearance angle $17^{\circ}$; number of revolution $4200 \mathrm{rpm}$, and feed speed in of range of 4-11 $\mathrm{m} \cdot \mathrm{min}^{-1}$.

Heat treatment of selected Turkish wood species (soft and hard wood) does not affect surface roughness (Budakçı et al. 2013). On the other hand, Gündüz et al. (2008) reported that surface roughness of modified Camiyanı Black Pine wood (Pinus nigra Arn. subsp. pallasiana var. pallasiana) is lower. Similar findings were stated by Kisselbach (2009) concerned modified timber for window construction. Analogous results of decreased roughness were described by Kvietková et al. (2015) in case of birch wood after thermal treatment. Findings of the experiments by Škaljić et al. (2009) revealed that roughness $R$ a of thermally modified beech-wood was very close to the same values of steamed beech-wood samples. However, the surface roughness of heat-treated beech processed by milling was slightly higher than that of untreated wood (as measured by $R a, R q, R t, R k$, and $R k+R p k+R v k$ ) (Ispas et al., 2016). The latter findings were confirmed by Hacibektasoglu et al. (2017), who revealed that heattreating beech (Fagus sylvatica L.) for $1 \mathrm{~h}$ and $2 \mathrm{~h}$ had a negligible effect on the processing roughness after planning, measured across the grain by $R k$. Moreover, the $R k$ increased by $15 \%$ for $3 \mathrm{~h}$ and $4 \mathrm{~h}$ of treatment and with approximately $33 \%$ for treating the beech for $5 \mathrm{~h}$ and $6 \mathrm{~h}$.

The researches by Škaljić et al. (2009) have shown that the samples of planed surface of oak-wood (Quercus L.) had the best quality and the samples of fir wood (Abies alba Mill.) had the highest values of surface roughness $(R a)$. In both cases the specimens were machined by planing in radial directions with two knives at $6,12,18$ and $24 \mathrm{~m} \cdot \mathrm{min}^{-1}$ feed speed. The cutting depth of $2.0 \mathrm{~mm}$ was constant and knife rake angle was $15^{\circ}$. The machining experiments were carried out using a single cutter-block of a Weinig Powermat 400. The cutter-block with a diameter of $\varnothing 125 \mathrm{~mm}$ rotated at 6000 revolutions per minute (rpm) (Škaljić et al., 2009).

Öhman et al. (2015) found that, after planing, the average surface quality of a whole batch of boards made of Scots pine (Pinus sylvestris L.) can be increased by adding water to the surface short before planing. However, a positive impact cannot be guaranteed for single boards (Öhman et al., 2015).

After planing with dull knives, the wood cells were greatly distorted and cell walls were extensively damaged, particularly at and near the glue line. On the other hand, sharp knives caused much less damage to cell walls and the cells had a normal or near-normal appearance (Singh et al., 2002).

Industrial development and international competitiveness impose higher demands on wood industry. New technologies and cutting materials are the key to successful productivity in the manufacturing process. From the industrial point of view, the frequency of tool changes should be minimised and simultaneously the production costs per each piece ought to be reduced (Aguilera et al., 2003). Therefore, the aim of this paper was to evaluate the effect of the cutting tool material (wear) on the surface quality of planed semi-finished pine beams for window frames.

\section{MATERIALS AND METHODS \\ 2. MATERIJALI I METODE}

\subsection{Materials}

2.1. Materijali

The samples in the research were wooden beams made of glued laminated Scots pine lamellae (Pinus sylvestris L.), generally used for the production of window frames. Semi-finished products were provided in the form of 6-meter-long beams initially machined by suppliers. It should be emphasised that the total number of samples was not limited because beam planing was conducted until there were no defects on the machined surface. The working drawing of the semi-finished product includes dimensions, wood species, surface and main features as shown in Fig. 1.

\subsection{Methods \\ 2.2. Metode}

Tests were carried out on the moulding machine for four-side machining type of Superset $\mathrm{mt}$ (the planer moulder, SCM Group SPA, Italy). This test was con- 


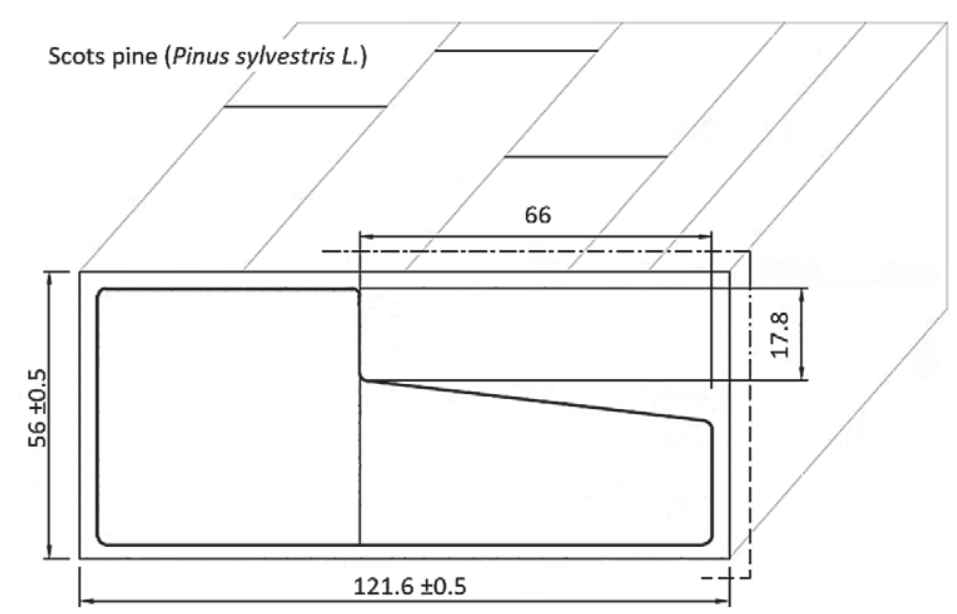

a)

Figure 1 Working drawing (a) and view of semi-finished material (b)

Slika 1. a) Radni crtež za proizvodnju elemenata za prozore, b) izgled drvenoga lameliranog elementa za proizvodnju prozora

ducted on the first out of three operations in the production process and was associated with shaping of the workpiece (Fig. 2).

The test was carried on until no defects associated with the tool wear (material pulled out, cracks) could be observed on the planed surface of the element. The element was classified as unfit for further production process based on visual inspection. One of the important indicators of the process evaluation was the number of metres of machined wood meeting the quality requirements, meaning that wood surface of the remaining machined parts were of poor quality. The length of the properly cut beams could be considered as a wear factor (Aguilera et al., 2016).

The occurrence of defects in the material and on the surface can be divided into those dependent and independent on humans. The first group, as previously mentioned, was associated with the occurrence of cracks and knots of the material. In the second group, there are mostly prints and scratches in the material, as well as fibres torn away from the surface.

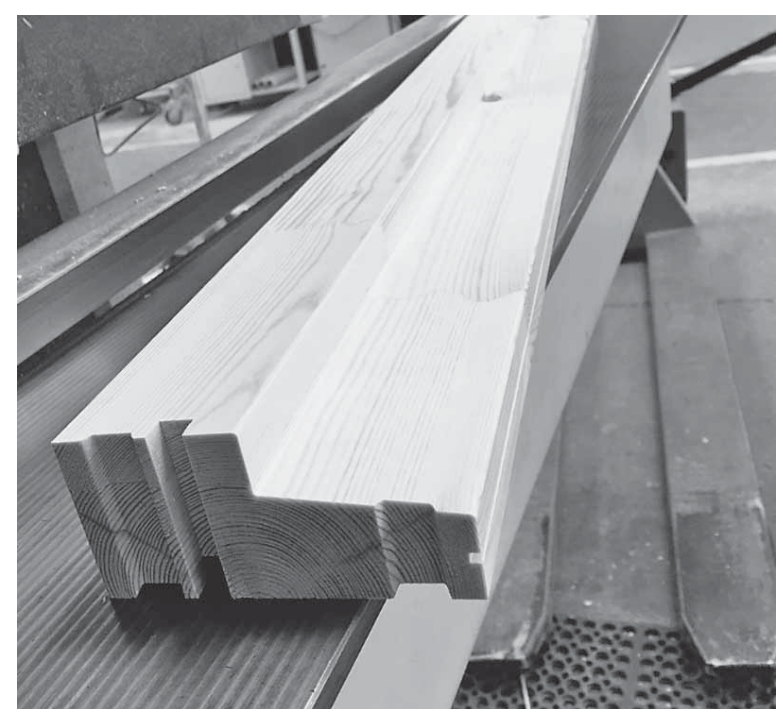

Figure 2 View of the material after machining Slika 2. Izgled drvenoga lameliranog elementa nakon strojne obrade

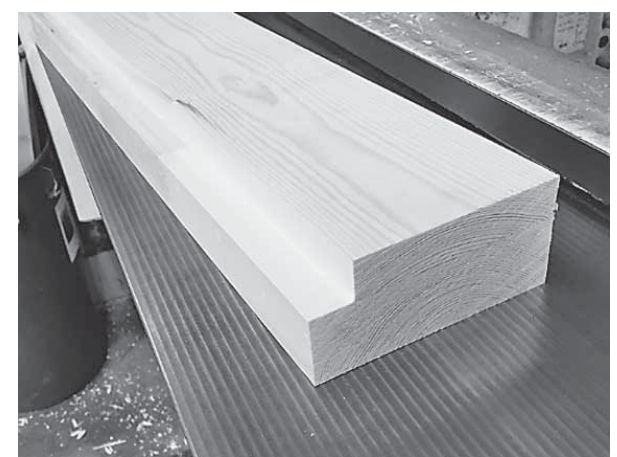

b)

The occurrence of any of the above mentioned defects usually disqualified the material for further machining. Some of them could be corrected but it required additional machining (re-work) using sanding machines.

\subsection{Tool and machine tool \\ 2.3. Alat i stroj}

A set of blades necessary to equip the planer moulder Superset $\mathrm{mt}$ consisted of 8 knives $80 \mathrm{~mm}$ long, 2 knives $130 \mathrm{~mm}$ long and 2 knives $150 \mathrm{~mm}$ long. Such equipment provided the opportunity to implement all the necessary processes in one machine setting. Table 1 presents the main woodworking information.

In the research, a Tersa ${ }^{\circledR}$ system planer head was used of $140 \mathrm{~mm}$ in diameter (Fig. 3). The knife was made of the standard uncoated solid carbide (HW, K a group of application according to ISO (Tersa 2014)) of micrograin quality, and additionally for comparison blades were made of chrome steel (CR, HR $13 \% \mathrm{Cr}$ (Tersa 2014)). The knives are also characterised by clearance angles $(\alpha)$ in the knife-in-hand system equal to $50^{\circ}(\mathrm{CR})$ and $35^{\circ}(\mathrm{HW})$ (Tersa 2014). Moreover, the Tersa $^{\circledR}$ system is characterised by great flexibility resulting from the system's modular design of identical aluminium washers.

The quality of machined parts was evaluated taking into account various aspects, including dimensions, presence of defects of the raw material, finishing with the surface texture. As shown in the working drawing, dimension deviations were approximately $\pm 0.2 \mathrm{~mm}$ (tolerance of $0.4 \mathrm{~mm}$ ). For this reason, they were measured with a calliper.

Before further machining, semi-finished wood elements were subjected to a thorough inspection. Moisture content $M C$, straightness of workpiece, as well as the presence of material defects, such as cracks and knots, were tested among other things.

The accepted deflection of an element of $1 \mathrm{~m}$ in length was $0.7 \mathrm{~mm}$ at the highest point. The density of the wooden element made of, for example, two or more lamellas could not be less than $500 \mathrm{~kg} / \mathrm{m}^{3}$. An impor- 

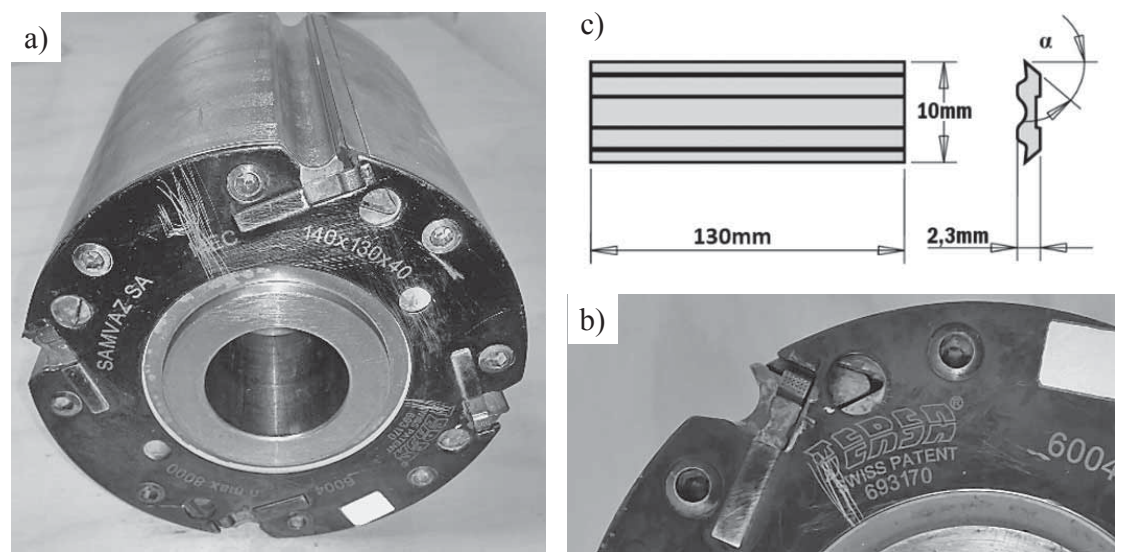

Figure 3 General (a) and detailed (b) view of Tersa ${ }^{\circledR}$ system planer head of $140 \mathrm{~mm}$ in diameter and main dimensions of the blade (c) (Tersa, 2018)

Slika 3. a) Prikaz cijele glave blanjalice, b) prikaz detalja u Tersa ${ }^{\circledR}$ sustavu promjera $140 \mathrm{~mm}$, c) glavne dimenzije noža (Tersa, 2018.)

Table 1 Main information on experimental procedure

Tablica 1. Najvažniji podatci o procesu obrade elemenata u eksperimentu

\begin{tabular}{|c|c|c|c|c|c|c|}
\hline & $\begin{array}{c}\text { Machine tool } \\
\text { Stroj }\end{array}$ & $\begin{array}{l}\text { No. of tool } \\
\text { spindles } \\
\text { Broj vratila }\end{array}$ & $\begin{array}{l}\text { Tool type } \\
\text { Vrsta alata }\end{array}$ & $\begin{array}{l}\text { Cutting depth, } \boldsymbol{a}_{\mathbf{p}} \\
\text { Visina dodatka za } \\
\text { obradu } \\
\mathrm{mm}\end{array}$ & $\begin{array}{c}\text { Feed per tooth } \boldsymbol{f}_{\mathrm{z}} \\
\text { Posmak po zubu } \\
\mathrm{mm}\end{array}$ & $\begin{array}{c}\text { Spindle speed } \boldsymbol{n} \\
\text { Frekvencija vrtnje } \\
\text { vratila } \\
\text { rpm }\end{array}$ \\
\hline \multirow{6}{*}{$\begin{array}{c}\text { Shaping } \\
\text { Oblikovanje }\end{array}$} & \multirow{6}{*}{$\begin{array}{c}\text { SCM } \\
\text { Superset } \\
\text { CLASS }\end{array}$} & 1 & \multirow{6}{*}{$\begin{array}{l}\text { Tersa }{ }^{\circledR} \text { head } \\
\varnothing=140 \mathrm{~mm}\end{array}$} & \multirow{6}{*}{0.8} & \multirow{6}{*}{0.5} & \multirow{6}{*}{6000} \\
\hline & & 2 & & & & \\
\hline & & 3 & & & & \\
\hline & & 4 & & & & \\
\hline & & 5 & & & & \\
\hline & & 6 & & & & \\
\hline
\end{tabular}

tant parameter under control was the moisture content that was to be $M C 12 \% \pm 2 \%$.

The surface texture measurements $(\mathrm{P}-$ profile, $\mathrm{R}$ - profile, $\mathrm{W}$ - profile) were carried out with the surface roughness tester Hommelwerk Standard 1000. Each 1-m of the sample, where defects were observed, was cut-off from the 6-m specimen, and then measured. At each measurement point with a visible defect, three measurements were done perpendicularly to the side surface of the workpiece for averaging the results. The results of the measurement of the testing set were recorded in the measuring table, along with the obtained total length of the machined wood.

Additionally, the surface topography measurements of the processed products were made with the 3D Optical Profiler S Neox (Sensofar 2017) with objective $20 \times$ magnification and $Z$ scanning range of 83 micrometres. This system is one of the methods of 3D optical measurements applied in the study of surface topography, which allowed us to scan the samples with a confocal technique.

\section{RESULTS AND DISCUSSION}

\section{REZULTATI I RASPRAVA}

The results of six tests of total lengths of machined frame beams (together with corresponding number of beams) are presented in Table 2. In order to perform a correct analysis, results obtained from machining with blades made of solid carbide (HW) were compared with results from the same test performed with blades made of chrome steel (CR). It should be emphasized that the productivity of the process in the first case is nearly 3.5 times higher than in the second one (length Median $(\mathrm{HW})=468 \mathrm{~m}$ and length Median $(\mathrm{CR})=131 \mathrm{~m})$ (Fig. 4). The analysis took into account the cost of production and especially the difference in the cost of equipping the machine with a given type of knife. The total cost of equipping the heads with knives made of HW was almost twice higher than with knives made of CR. Nevertheless, the average production cost of 1 meter of material in the first case (the head equipped with HW knives) was about $30 \%$ less than the second one (CR knives used).

Measuring the surface texture enabled the comparison of surface structure processed with the new blades and those that showed wearing. In 2D measurements (Gurau and Irle, 2017; Zhong et al., 2013; Sandak and Tanaka, 2003; Sandak et al., 2004; Sandak and Negri, 2005), the evaluation length amounted to $12.5 \mathrm{~mm}$. During the measurements, the following parameters were adopted: evaluation length $\ln =12.5$ $\mathrm{mm}$, cut off value $\lambda \mathrm{c}=2.5 \mathrm{~mm}$, cut off ratio $\lambda \mathrm{c} / \lambda \mathrm{s}=$ 300, sampling interval $1.5 \mu \mathrm{m}$ and filter type ISO 11562(M1). The stylus end was conical (taper angle of cone: $60^{\circ}$ ) with a spherical tip (tip radius $r_{\text {tip }}=2 \mu \mathrm{m}$ ). These values were adopted since the main objective was to assess the surface condition on maximum possible length, which was limited by maximum measuring length of the used device. 
Table 2 Total length of machined frame beams together with corresponding number of planed beams in parenthesis vs. selected types of blade material

Tablica 2. Ukupna duljina lameliranih elemenata obrađenih dvama različitim noževima za blanjanje (pripadajući broj obrađenih elemenata naveden je u zagradi)

\begin{tabular}{|c|c|c|c|c|c|c|c|}
\hline & & \multicolumn{6}{|c|}{$\begin{array}{l}\text { Total length of machined frame beams (in m) and number of planed } \\
\text { beams in brackets / Ukupna duljina obrađenih lameliranih elemenata } \\
\text { (m) s pripadajućim brojem obrađenih elemenata u zagradi }\end{array}$} \\
\hline \multicolumn{2}{|c|}{$\begin{array}{l}\text { No. of test samples } \\
\text { Redni broj mjerenja }\end{array}$} & 1 & 2 & 3 & 4 & 5 & 6 \\
\hline \multirow{2}{*}{$\begin{array}{l}\text { Knife material } \\
\text { Materijal noža } \\
\text { za blanjanje }\end{array}$} & $\begin{array}{l}\text { Solid carbide (HW) } \\
\text { tvrdi metal }\end{array}$ & $389(65)$ & $437(73)$ & $499(83)$ & $290(49)$ & $569(95)$ & $525(88)$ \\
\hline & $\begin{array}{l}\text { Chrome steel } 13 \% \mathrm{Cr}(\mathrm{CR}) \\
\text { kromirani čelik }\end{array}$ & $100(17)$ & 159 (27) & $200(34)$ & $103(18)$ & 79 (13) & $299(50)$ \\
\hline
\end{tabular}

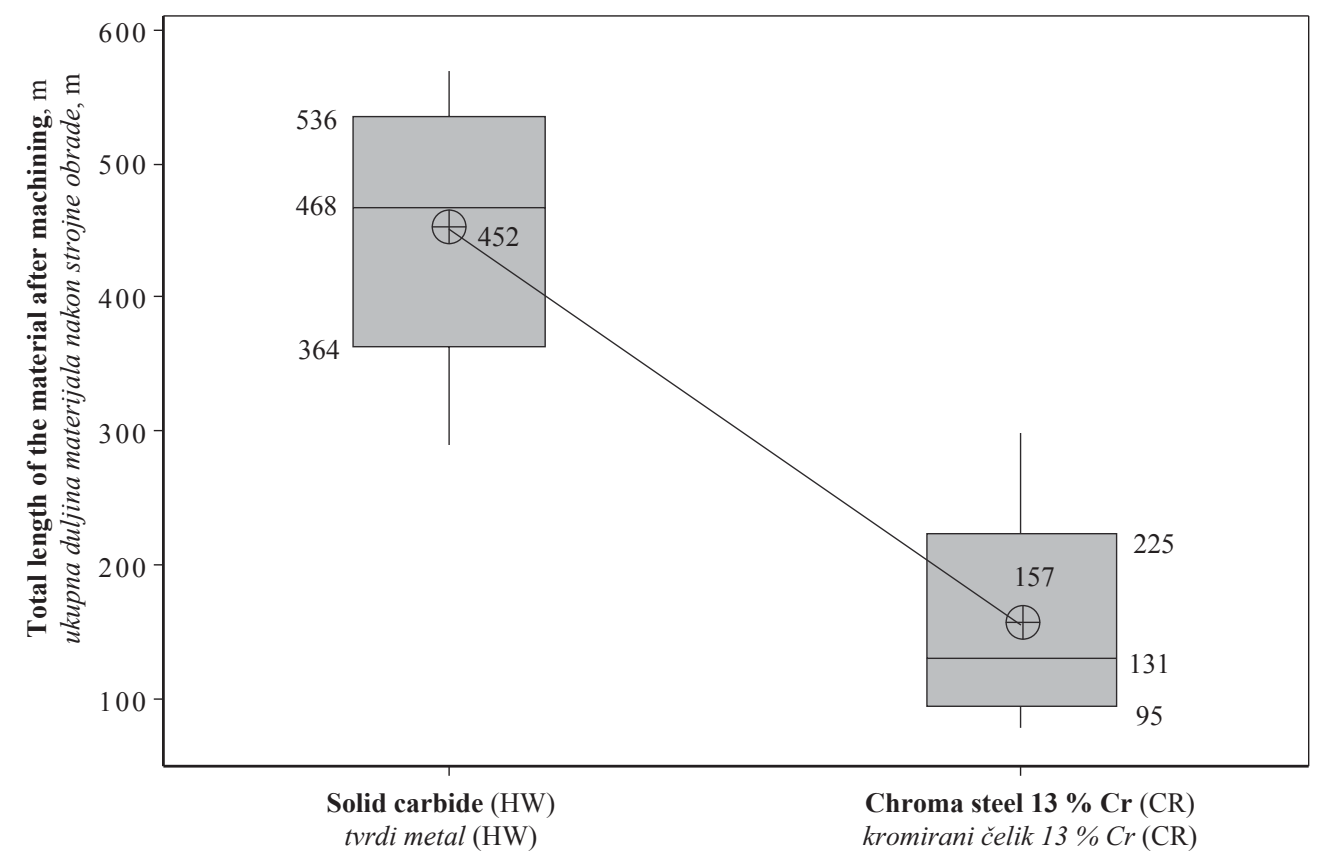

Figure 4 The mean value and value dispersion of total length of machined frame beams vs. selected types of blade material (box plot presents: the mean, median, interquartile range box and data range)

Slika 4. Srednja vrijednost i rasipanje podataka o ukupnoj duljini obrađenih lameliranih elemenata s obzirom na vrstu materijala noža (na grafu su prikazane srednje vrijednosti, medijani, interkvartilni raspon i raspon podataka)

Comparing the profiles between the sample manufactured with a set of new knives and the sample obtained after manufacturing n-meters of the product, significant changes can be noticed in the appearance of the primary profile (the profile of waviness was added for better visualisation). The profiles of the first samples, i.e. after manufacturing $6 \mathrm{~m}$ long beams, were smooth and the knives wear was not observed (Fig. 5). The surface texture parameters for the primary and roughness profiles were: $R a=(2.48-3.20 \mu \mathrm{m}), R z=$
$(16.90-21.25 \mu \mathrm{m}), R v=(7.55-8.82 \mu \mathrm{m}), R p=(9.61$ - $14.13 \mu \mathrm{m}), P z=(18.86-25.52 \mu \mathrm{m}), P v=(0.77$ $18.18 \mu \mathrm{m})$ and $P p=(4.08-14.46 \mu \mathrm{m})$.

Measurements of the last defect-free element were made in two areas that had been assessed as the most damaged by visual inspection. Three parallel measurements at 7-mm intervals were done perpendicularly to the side surface of the workpiece (perpendicularly to the feeding direction). The results of the measurement of the testing set, i.e. the last samples, are presented in meas-

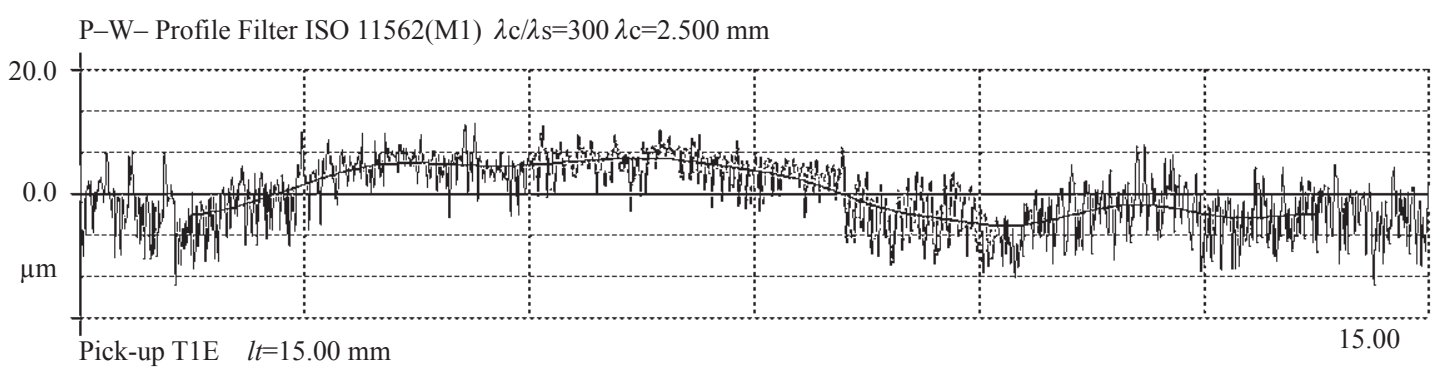

Figure 5 Example of $\mathrm{P}$ - and $\mathrm{W}$ - profile of the first machined sample

Slika 5. Primjer profila $\mathrm{P}$ i W za prvi obrađeni uzorak 
Table 3 Roughness parameters of the last element machined by Solid Carbide Blades (HW)

Tablica 3. Parametri hrapavosti posljednjeg elementa obrađenoga noževima od tvrdog metala (HW)

\begin{tabular}{|c|c|c|c|c|c|c|c|c|}
\hline \multirow{2}{*}{$\begin{array}{l}\text { No. of test samples } \\
\text { Redni broj mjerenja }\end{array}$} & \multirow{2}{*}{$\begin{array}{l}\text { No. of area } \\
\text { Broj površine }\end{array}$} & \multirow{2}{*}{$\begin{array}{l}\text { No. of measurement } \\
\text { Broj mjerenja }\end{array}$} & \multicolumn{6}{|c|}{ Roughness parameters / Parametri hrapavosti } \\
\hline & & & $R t, \mu \mathrm{m}$ & $R z, \mu \mathrm{m}$ & $R p, \mu \mathrm{m}$ & $R v, \mu \mathrm{m}$ & $R k u$ & Rsk \\
\hline \multirow{2}{*}{1} & 1 & 3 & 59.89 & 33.33 & 29.64 & 16.41 & 5.151 & -0.378 \\
\hline & 2 & 3 & 52.13 & 33.18 & 15.83 & 12.19 & 5.700 & -0.973 \\
\hline \multirow{2}{*}{2} & 1 & 2 & 57.50 & 43.03 & 24.25 & 15.67 & 3.243 & -0.050 \\
\hline & 2 & 1 & 68.54 & 37.43 & 34.03 & 10.30 & 11.584 & 0.734 \\
\hline \multirow{2}{*}{3} & 1 & 1 & 44.75 & 34.43 & 25.82 & 14.74 & 3.629 & -0.046 \\
\hline & 2 & 2 & 40.32 & 31.89 & 15.88 & 17.93 & 4.372 & -0.748 \\
\hline \multirow{2}{*}{4} & 1 & 1 & 33.31 & 21.04 & 17.78 & 9.66 & 5.539 & -0.389 \\
\hline & 2 & 2 & 39.00 & 26.52 & 12.51 & 10.97 & 5.603 & -0.973 \\
\hline \multirow{2}{*}{5} & 1 & 2 & 51.51 & 32.19 & 13.31 & 11.94 & 11.243 & -2.165 \\
\hline & 2 & 1 & 39.21 & 22.89 & 16.70 & 10.23 & 5.859 & -0.884 \\
\hline \multirow{2}{*}{6} & 1 & 2 & 59.66 & 37.54 & 26.75 & 11.49 & 6.712 & 0.222 \\
\hline & 2 & 1 & 46.74 & 34.84 & 27.55 & 16.47 & 3.774 & 0.113 \\
\hline
\end{tabular}

Table 4 Roughness parameters of the last element machined by Chrome Steel Blades $13 \% \mathrm{Cr}(\mathrm{CR})$

Tablica 4. Parametri hrapavosti posljednjeg elementa obrađenoga noževima od kromiranog čelika (CR)

\begin{tabular}{|c|c|c|c|c|c|c|c|c|}
\hline \multirow{2}{*}{$\begin{array}{l}\text { No. of test samples } \\
\text { Redni broj mjerenja }\end{array}$} & \multirow{2}{*}{$\begin{array}{c}\text { No. of area } \\
\text { Broj površine }\end{array}$} & \multirow{2}{*}{$\begin{array}{c}\text { No. of measurement } \\
\text { Broj mjerenja }\end{array}$} & \multicolumn{6}{|c|}{ Roughness parameters / Parametri hrapavosti } \\
\hline & & & $R \mathrm{t}, \mu \mathrm{m}$ & $R z, \mu \mathrm{m}$ & $R p, \mu \mathrm{m}$ & $R v, \mu \mathrm{m}$ & $R k u$ & Rsk \\
\hline \multirow{2}{*}{1} & 1 & 1 & 45.03 & 29.74 & 13.83 & 14.34 & 7.119 & -1.163 \\
\hline & 2 & 3 & 51.52 & 27.86 & 11.68 & 12.02 & 14.463 & -2.017 \\
\hline \multirow{2}{*}{2} & 1 & 3 & 39.22 & 25.70 & 14.74 & 11.52 & 7.044 & -1.216 \\
\hline & 2 & 3 & 40.58 & 29.70 & 18.58 & 11.50 & 4.045 & -0.472 \\
\hline \multirow{2}{*}{3} & 1 & 1 & 39.52 & 24.43 & 17.33 & 11.69 & 5.609 & -1.009 \\
\hline & 2 & 3 & 34.58 & 21.21 & 13.54 & 11.51 & 3.900 & -0.557 \\
\hline \multirow{2}{*}{4} & 1 & 1 & 26.74 & 20.91 & 8.13 & 11.59 & 3.669 & -0.753 \\
\hline & 2 & 3 & 36.28 & 26.14 & 18.56 & 13.36 & 3.679 & -0.383 \\
\hline \multirow{2}{*}{5} & 1 & 1 & 29.38 & 20.93 & 10.36 & $8.42 *$ & 4.433 & -0.857 \\
\hline & 2 & 2 & 29.22 & 25.49 & 13.88 & 12.72 & 3.594 & -0.508 \\
\hline \multirow{2}{*}{6} & 1 & 2 & 30.49 & 22.69 & 11.44 & 11.02 & 4.451 & -0.795 \\
\hline & 2 & 2 & 54.97 & 36.62 & 19.99 & 10.86 & 6.024 & -0.827 \\
\hline
\end{tabular}

*outlier observation from 1.5 times the interquartile range (Q3 - Q1) / podatak koji je izvan interkvartilnog raspona (Q3 - Q1)

urement tables (see Appendix). Taking into account maximum $R t$ values for each area of test sample, as one of texture parameters significantly affected by scratches due to its use of peak values, the data tables were created and further analysed (Table 3 and 4).

The maximum value of the total profile height$R t(68.54 \mu \mathrm{m})$ was observed in Sample \#2 for the sec-

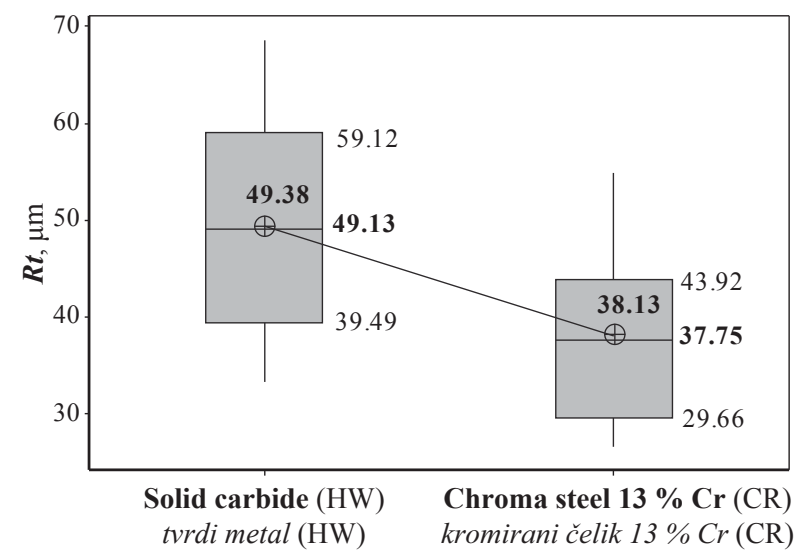

a)

Figure 6 The mean value and value dispersion of total height $R t$ (a) and maximum height $R z$ (b) of the profile vs. selected types of blade material (the box plot presents: the mean, median, interquartile range box and data range)

Slika 6. Srednja vrijednost i rasipanje podataka: a) o ukupnoj visini $R t$ i b) o maksimalnoj visini $R z$ profila obrađene površine pri obradi dvama različitim noževima (na grafu su prikazane srednje vrijednosti, medijani, interkvartilni raspon i raspon podataka) ond area $(\mathrm{HW})$ and it was about $25 \%$ greater than the maximum value for CR blade (Sample \#6 second area). In both cases, the range of $R t$ parameter was significant and amounted to $33.31-68.54 \mu \mathrm{m}$ (HW) and $26.74-$ $54.97 \mu \mathrm{m}$ (CR). Generally, mean and median were about $30 \%$ greater for HW blade (Fig. 6). Similar situation occurred for maximum height of the profile $(R z)$.

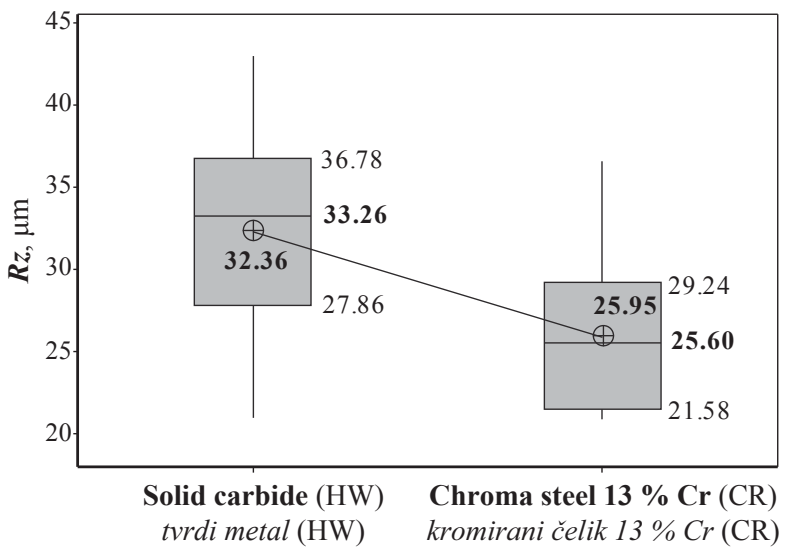

b) 


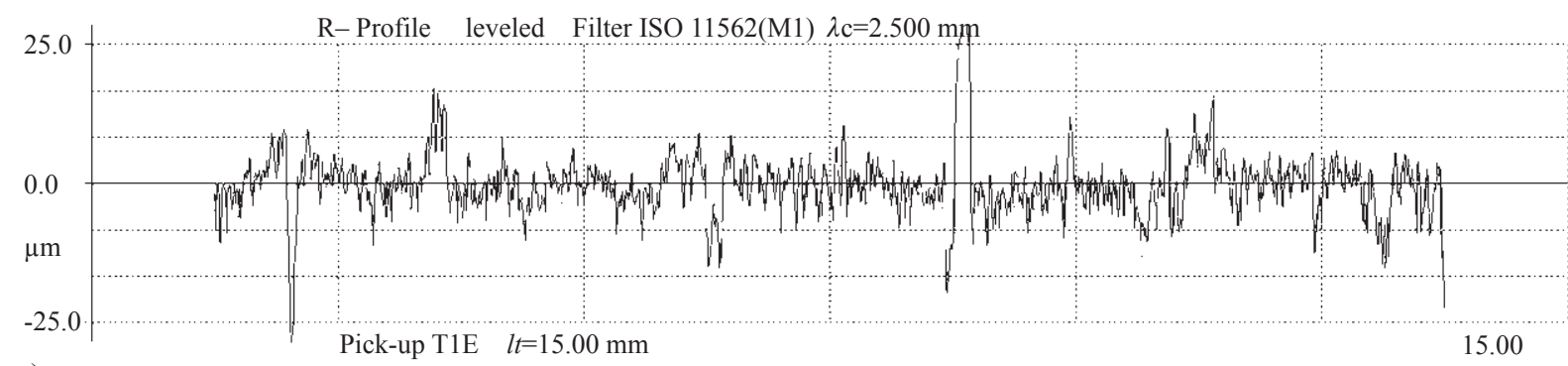

a)

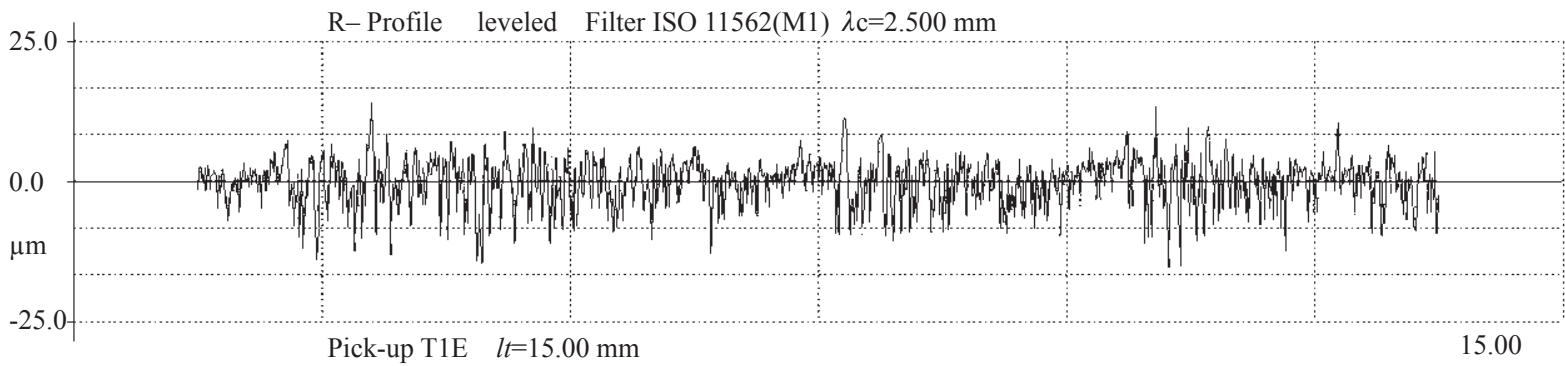

b)

Figure 7 R-profiles of Sample \#2 machined with HW blades (a) and Sample \#5 planed with CR blades (b)

Slika 7. a) R-profil uzorka \#2 obrađenoga nožem od tvrdog metala, b) R-profil uzorka \#5 obrađenoga nožem od kromiranog čelika

However, the inter-quartile range was $8.92 \mu \mathrm{m}(\mathrm{HW})$ and $7.66 \mu \mathrm{m}(\mathrm{CR})$, respectively, whereas these ranges were twice as high as parameter Rt. This indicates a greater concentration of results around the median, which is related to the method of determining this parameter based on a sampling length and not on an evaluation length as in the case of $R t$.

Therefore, both minimum and maximum heights are characterised by particular maximum height of the profile $(R z)$ in the range of $20-45 \%$ for HW blade, and $12-45 \%$ for CR blade, which is smaller than corresponding values of profile total height $(R t)$. The maximum difference of $45 \%$ is presented by the example of the profile of Sample \#2 second area (HW) (Fig. 7a). Moreover, the profile for the minimum value of $12 \%$ observed in Sample \#5 second area (CR) is pictured in Figure $7 \mathrm{~b}$. Scratches, pull-outs and other damages to the machined wooden material could be distinctly ob- served on profiles, especially for HW blades, (the last element that does not fulfil quality requirements).

In both cases in question, the means and medians of maximum profile valley depth $(R v)$ were on similar level, whereas in case of maximum profile peak height $(R p)$, the difference between them was about $7 \mu \mathrm{m}$ (Fig. 8). The maximum values of $R v$ and $R p$ were $20 \%$ and $40 \%$ greater for HW blades, respectively. The range of the quartile box for HW blades was nearly two times higher than for CR blades. Likewise, the dispersion of measured values was doubled. However, the consideration of $8.42 \mu \mathrm{m}$ outliers leads to the conclusion that ranges of $R v$ can be comparable.

The Skewness (Rsk) values for most HW samples and all CR samples indicate that the height distribution was deviated upwards. In the case of one of Samples \#2 and both Samples \#6 (HW), the height distribution was deviated downwards. Meanwhile, in all examined
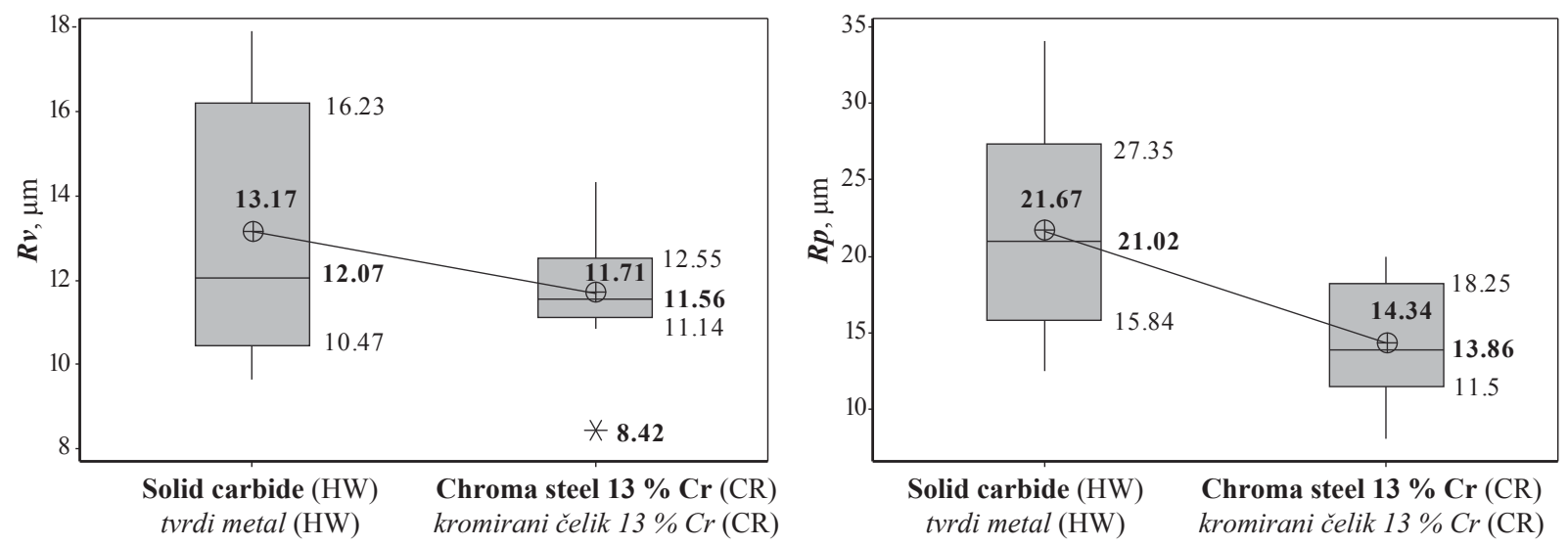

a)

b)

Figure 8 The mean value and value dispersion of maximum profile: valley depth $R v$ (a) and peak height $R p$ (b) vs. selected types of blade material (the box plot presents: the mean, median, interquartile range box and data range - outlier)

Slika 8. Srednja vrijednost i rasipanje podataka: a) o dubini udoline $R v$ i b) o visini vrha $R p$ maksimalnog profila površine obrađene dvama različitim noževima (na grafu su prikazane srednje vrijednosti, medijani, interkvartilni raspon i raspon podataka) 
Table 5 3D surface texture parameters of the last machined element without visible defects

Tablica 5. 3D parametri teksture površine posljednjega obrađenog elementa bez vidljivih grešaka

\begin{tabular}{|c|c|c|c|c|c|c|c|}
\hline & \multicolumn{6}{|c|}{ No. of test sample / Redni broj mjerenja } \\
\hline & & 1 & 2 & 3 & 4 & 5 & 6 \\
\hline \multirow{9}{*}{$\begin{array}{l}\text { 3D surface } \\
\text { texture } \\
\text { parameters } \\
3 \text { D parametri } \\
\text { teksture } \\
\text { površine }\end{array}$} & $S a, \mu \mathrm{m}$ & 5.09 & 10.99 & 6.51 & 7.09 & 4.27 & 7.30 \\
\hline & $S q, \mu \mathrm{m}$ & 7.05 & 17.18 & 8.68 & 9.35 & 5.83 & 12.02 \\
\hline & $S p, \mu \mathrm{m}$ & 23.60 & 25.57 & 57.36 & 31.98 & 26.99 & 65.61 \\
\hline & $S v, \mu \mathrm{m}$ & 55.79 & 117.46 & 51.27 & 57.80 & 44.58 & 80.11 \\
\hline & $S z, \mu \mathrm{m}$ & 79.39 & 143.03 & 108.63 & 89.79 & 71.57 & 145.73 \\
\hline & Sku & 9.45 & 11.57 & 5.30 & 6.38 & 6.20 & 12.44 \\
\hline & Ssk & -2.11 & -2.79 & -0.51 & -1.69 & -1.58 & -1.76 \\
\hline & $\Delta Z, \mu \mathrm{m}$ & 55.26 & 67.62 & 49.69 & 45.26 & 18.62 & 32.61 \\
\hline & $A,^{\circ}$ & 12.16 & 11.61 & 8.13 & 8.63 & 4.08 & 6.91 \\
\hline
\end{tabular}

cases, the tip geometry of peaks and valleys was sharp, Kurtosis $(R k u)>3$.

For a more detailed analysis of the damage to the surface, some 3D measurements of the surface condition were made with 3D Optical Profiler S Neox (f. Sensofar 2017) (Fig. 9 and 10). Moreover, the 3D measurements have given a complete image of the surface condition as a critical element of the entire machining process. The obtained results are in agreement with findings by Zongh et al. (2013). The results of selected 3D surface texture parameters are shown in Table. 5.

In most of the samples, root mean square height $(S q)$ values were about $30-40 \%$ higher than arithmetical mean height $(\mathrm{Sa})$ values. Such differences are characteristic for irregular random profiles, where individual maximum and minimum height values, observed in the profile, have greater effect on $S q$ than on
$\mathrm{Sa}$. This was particularly noticeable in Sample \#2 and Sample \#6, when these differences increased to about $55-65 \%$. The unevenness evaluated using the above height parameters $S q$ and $S a$ reflects general texture of the machined wood having considered scratched areas caused by worn blades.

For Samples \#1, \#4 and \#5, maximum height $(\mathrm{Sz})$ values were in the range of $70-90 \mu \mathrm{m}$. However, in other cases the surface damages were very large with high scratches, values of the $S z$ parameter even up to $146 \mu \mathrm{m}$. The valley's depths were predominant and maximum pit depth $(S v)$ represented $62-82 \%$ of maximum height $(S z)$. In Samples \#3 and \#6, the distribution among peak heights and valley's depths was more equal and maximum peak height $(S p)$ represented $52 \%$ and $45 \%$ of the maximum height $(\mathrm{Sz})$.

Presented Skewness parameters (Ssk) were used to evaluate deviations in the height distribution. Nega-

a)
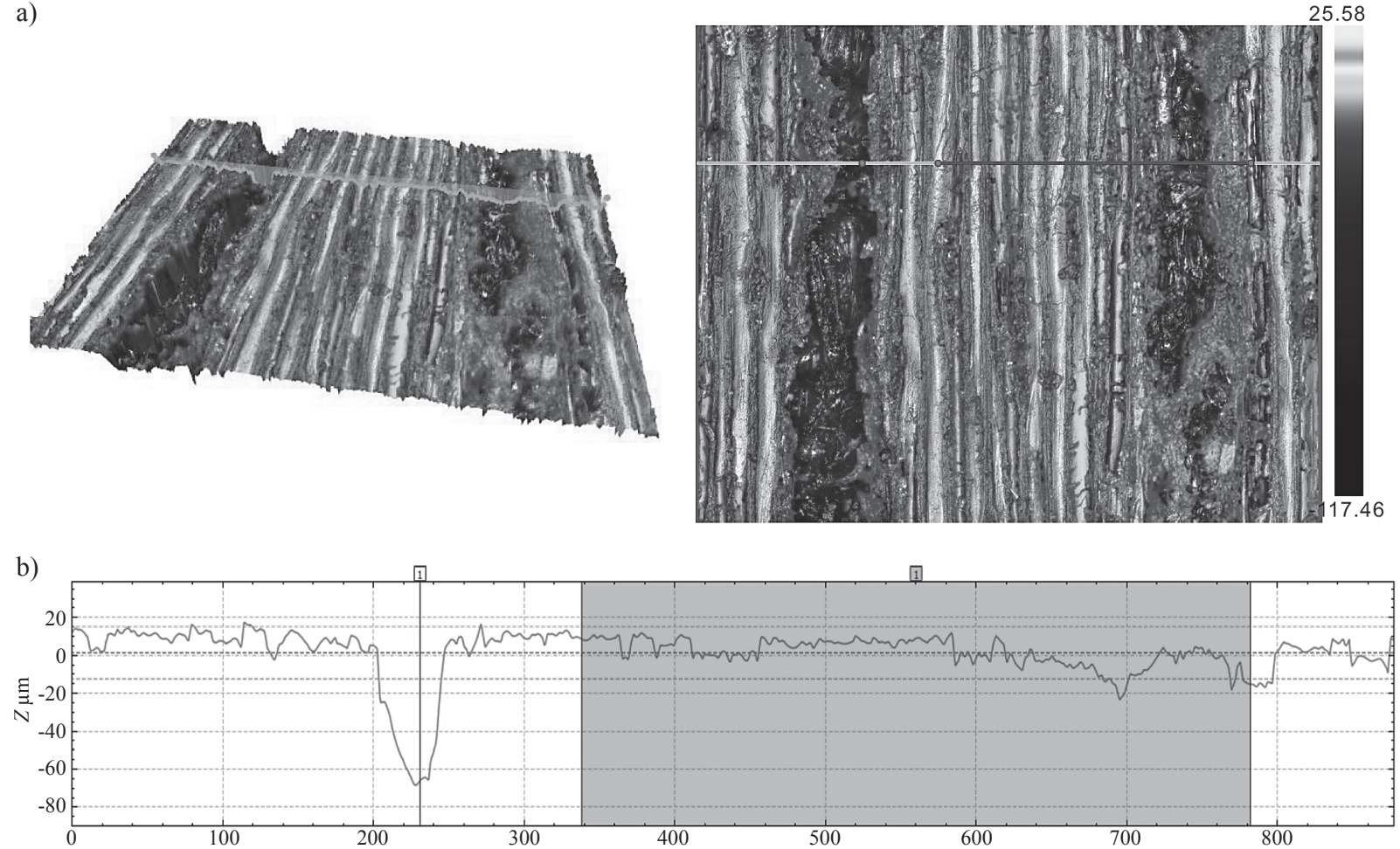

Figure $93 \mathrm{D}$ surface topography (a) and 2D profile (b) of the $2^{\text {nd }}$ test sample

Slika 9. a) 3D topografija površine, b) 2D profil drugoga ispitnog uzorka 
a)
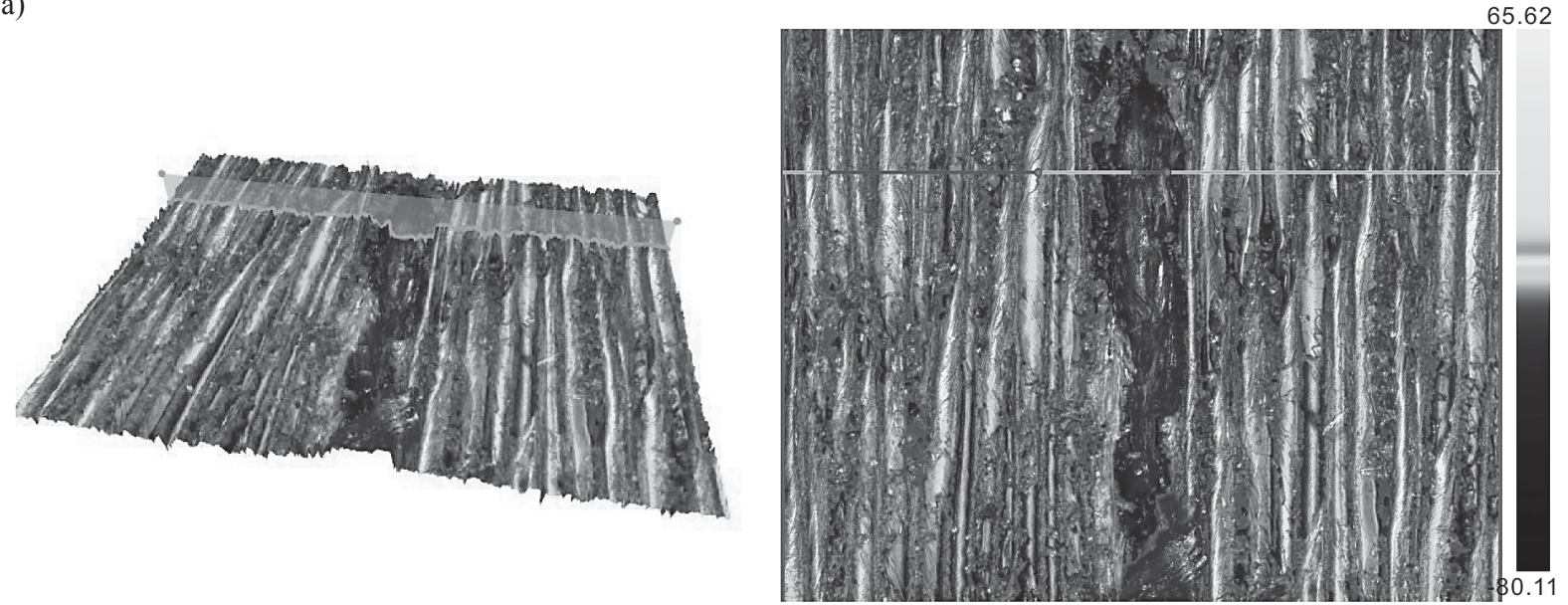

b)

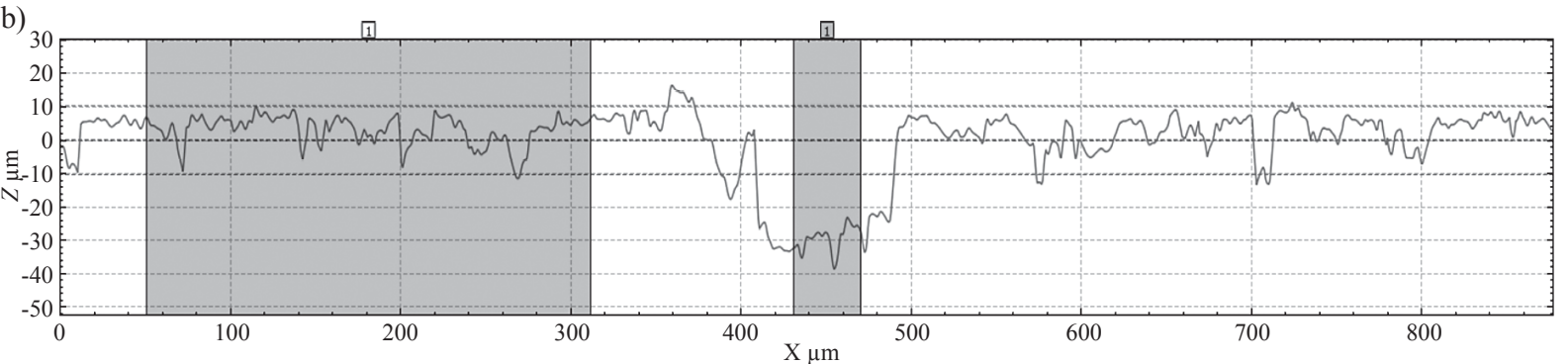

Figure $103 \mathrm{D}$ surface topography (a) and 2D profile (b) of the $6^{\text {th }}$ test sample Slika 10. a) $3 D$ topografija površine, b) $2 D$ profil šestoga ispitnog uzorka

tive skewness $(S s k=-2.79$ to -0.51$)$ indicates the presence of deep valleys below a smoother plateau. In all of the examined cases, Kurtosis $(S k u)$ value was higher than 3, and in Sample \#1, \#2 and \#6 exceeded 9, which indicates the presence of inordinately sharp deep valleys in the texture.

Since deep scratches are the key factor for surface quality before painting, their $\Delta Z$ heights were established (Table 5). This height $(\Delta Z)$ was calculated as a height between the points (if there is 1 extreme value - Samples \#1 $\div$ \# - pink line, Fig. 9b) or central point of the mean line (if there are more extreme values Samples \#5 and \#6 - pink area, Fig.10b) and central point of the mean line of the plateau (pink areas). For the above points, the angle A (Table 5), which gives the information about distance between them, was also determined. Height $(\Delta Z)$ and maximum pit depth $(S v)$ in Sample \#1, \#3 and \#4 were comparable, while differences among the remaining samples were significant. In the case of Sample \#5 and Sample \#6, the $\Delta Z$ parameter was even 2.5 times smaller, meaning that height of the deep valley was smaller than $S v$ suggested. It should be emphasised that 3D surface texture parameters (ISO), together with additional parameters, are essential for defining irregular surface features.

\section{CONCLUSIONS}

\section{ZAKLJUČAK}

The conducted analysis of the planing process revealed that:

The obtained total length of machined beams was significantly higher for HW knives than for CR knives.
Even though the total cost of equipping the heads with knives made of HW was almost twice higher than those with CR knives, the production cost of 1 meter of glued pine beams was about $33 \%$ less.

It can be stated that the surface characteristics based on $2 \mathrm{D}$ parameters are definitely insufficient. It is important to analyse the results of the $3 \mathrm{D}$ measurements, which gives a complete picture of the surface condition as a critical element of the entire machining process.

\section{Acknowledgements - Zahvala}

The authors wish to thank the Dovista Polska Sp. z o.o. in Wedkowy (Poland) for tools and Scot pine wood samples used in the experiments. The authors would like to acknowledge the firm Optotom (Warsaw, Poland) for 3D surface texture measurements with the 3D Optical Profiler S Neox. Some parts of the paper were presented as a poster at the $23^{\text {rd }}$ International Wood Machining Seminar in Ozarow-Mazowiecki, Poland (26-31 May, 2017). We would like to thank anonymous reviewers for their constructive input and valuable suggestions.

\section{REFERENCES}

5. LITERATURA

1. Aguilera, A.; Méausoone, P. J.; Martin, P., 2003: A new methodology for wood cutting optimization in the secondary manufacturing processes. Holz als Roh- und Werkstoff, 61: 358-362.

2. Aguilera, A.; Munoz, H., 2011: Surface roughness and cutting power on Blackwood and Redwood planing. Maderas, Cienc. tecnol. [online], 13 (1): 19-28. 
Dobrzynski, Orlowski, Biskup: Comparison of Surface Quality and Tool-Life...

\section{APPENDIX - PRILOG}

Table 1A Selected roughness parameters of pine wood samples planed with HW blades

Tablica 1.A) Odabrani parametri hrapavosti uzoraka od borovine obrađenih blanjanjem noževima od tvrdog metala

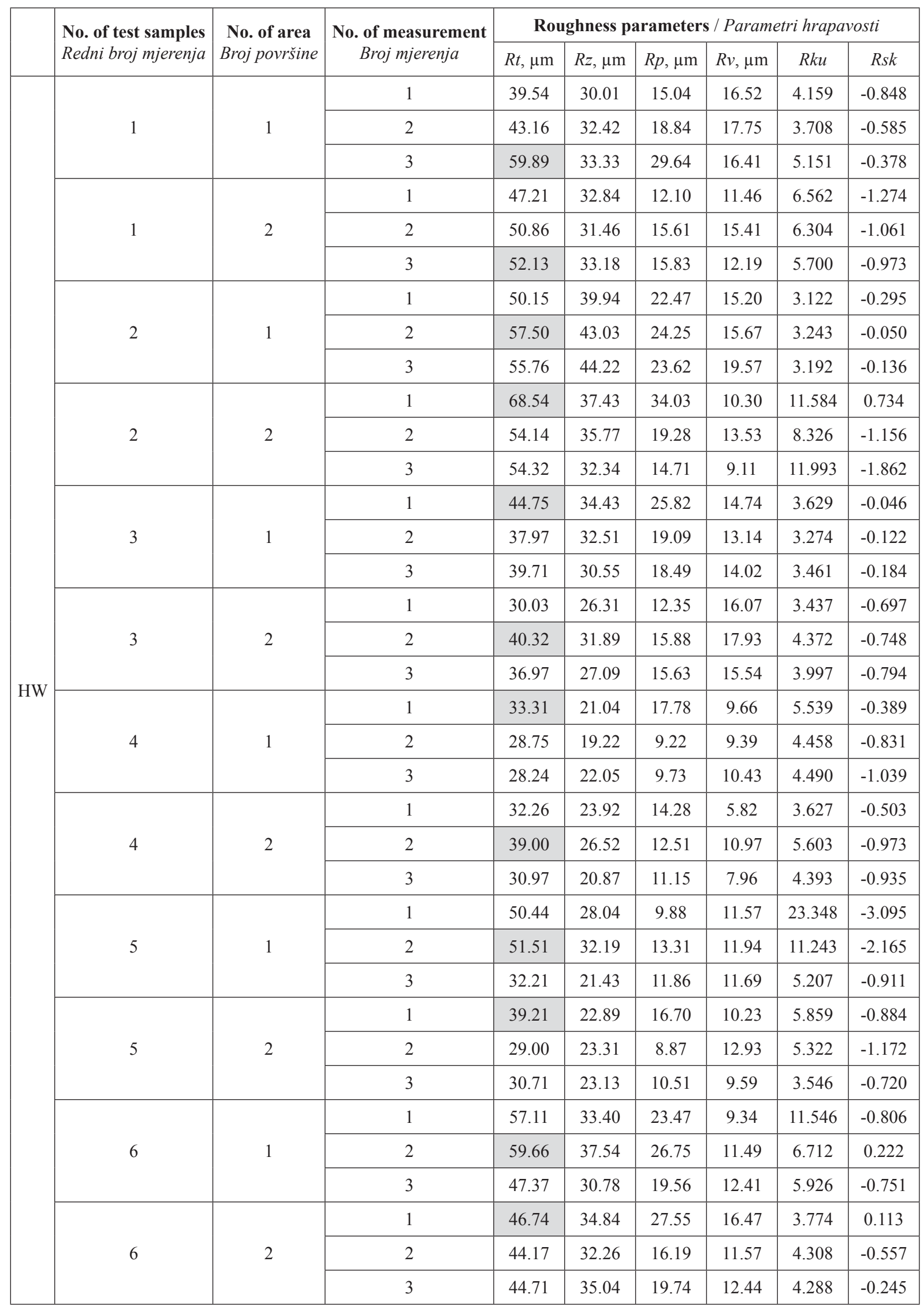

*the maximum parameters $R t$ of each analysed area are shaded / najveće vrijednosti parametra Rt svakoga analiziranog područja zasjenjene su 
Dobrzynski, Orlowski, Biskup: Comparison of Surface Quality and Tool-Life...

Table 2A Selected roughness parameters of pine wood samples planed with CR blades

Tablica 2.A) Odabrani parametri hrapavosti uzoraka od borovine obrađenih blanjanjem noževima od kromiranog čelika

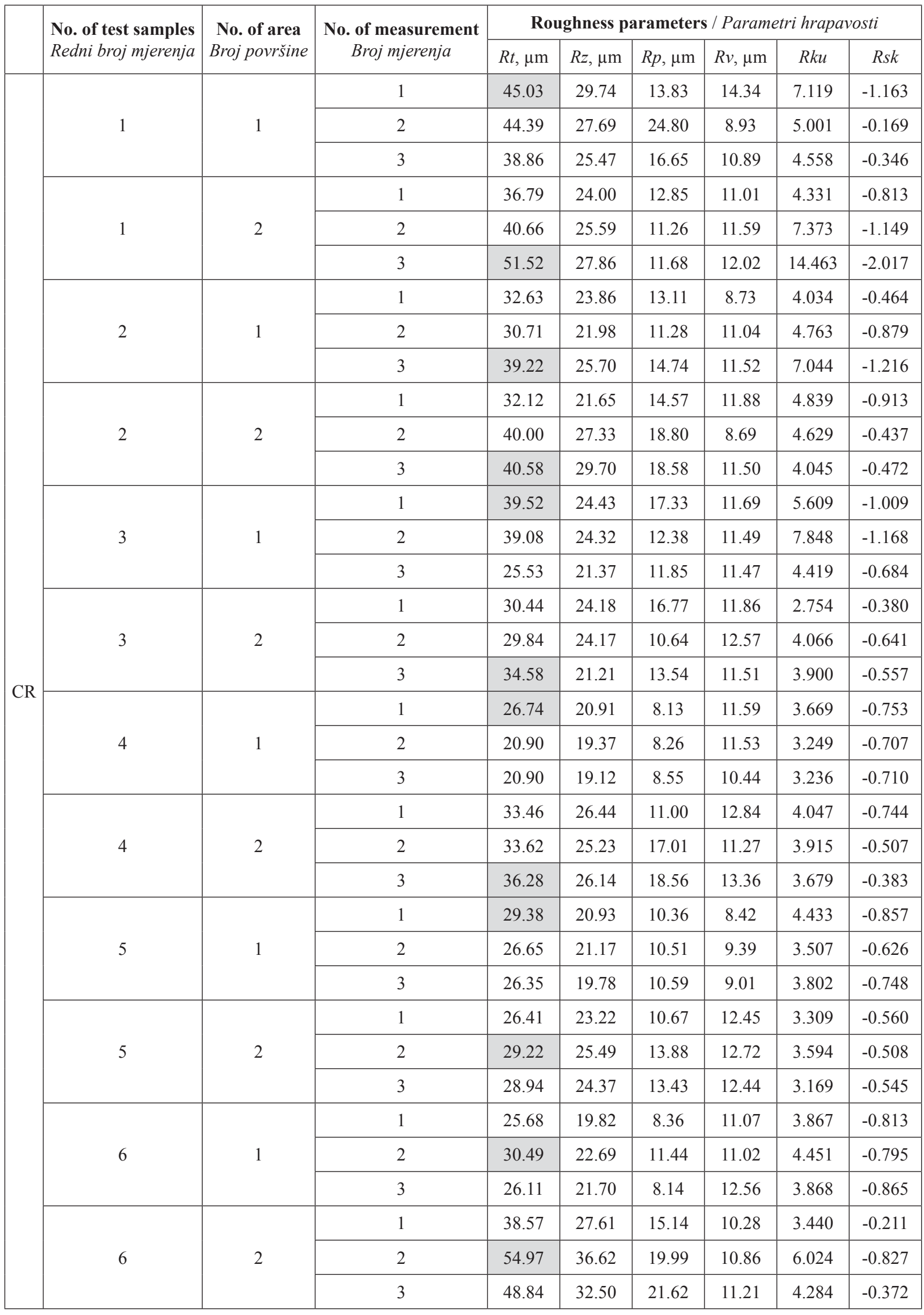

*the maximum parameters $R t$ of each analysed area are shaded / najveće vrijednosti parametra Rt svakoga analiziranog područja zasjenjene su 
3. Aguilera, A.; Rolleri, A.; Burgos, F., 2016: Cutting distance as factor to evaluate the quality of wood machined surfaces: A preliminary study. Maderas. Ciencia y tecnología, 18 (1): 3-8.

https://doi.org/10.4067/s0718-221x2016005000001.

4. Belleville, B.; Ashley, P.; Ozarska, B., 2016: Wood planing properties of Australian plantation-grown Eucalypts. Maderas. Ciencia y tecnología, 18 (3): 425-434. https://doi.org/10.4067/s0718-221x2016005000038.

5. Budakçı, M.; İlçe, A. C.; Gürleyen, T.; Utar, M., 2013: Determination of the surface roughness of heat-treated wood materials planed by the cutters of a horizontal milling machine. BioResource, 8 (3): 3189-3199.

https://doi.org/10.15376/biores.8.3.3189-3199.

6. Gottlöber, C.; Wagenführ, A.; Röbenack, K.; Ahmed, D.; Eckhardt, S., 2015: Strategies, concepts and approaches to avoid cutter-marks on wooden workpiece surfaces. In: Proceedings of the $22^{\text {nd }}$ International Wood Machining Seminar. R. Hernández and C. B. Cáceres, eds., Centre de Recherche sur les Matériaux Renouvelables, Université Laval, Quebec, Canada, pp. 223-233.

7. Gündüz, G.; Korkut, S.; Korkut, D. S., 2008: The effects of heat treatment on physical and technological properties and surface roughness of Camiyanı Black Pine (Pinus nigra Arn. subsp. pallasiana var. pallasiana) wood. Bioresource Technology, 99: 2275-2280. https://doi.org/10.1016/j.biortech.2007.05.015.

8. Gurau, L.; Irle, M., 2017: Surface roughness evaluation methods for wood products: A review. Curr Forestry Rep, 3 (2): 119-131. https://doi: 10.1007/s40725-017-0053-4.

9. Hacibektasoglu, M.; Campean, M.; Ispas, M.; Gurau, L., 2017: Influence of heat treatment duration on the machinability of beech wood (Fagus sylvatica L.) by planning. BioResource, 12 (2): 2780-2791. https://doi: 10.15376/biores.12.2.2780-2791.

10. Hernández, R. F.; Cool, J., 2008: Effects of cutting parameters on surface quality of paper birch wood machined across the grain with two planing techniques. Holz als Roh- und Werkstoff, 66: 147-154.

11. Ispas, M.; Gurau, L.; Campean, M.; Hacibektasoglu, M.; Racasan, S., 2016: Milling of heat-treated beech wood (Fagus sylvatica L.) and analysis of surface quality. BioResource, 11 (4): 9095-9111. https://doi: 10.15376/biores.11.4.9095-9111.

12. Jokerst, R. W.; Stewart, H. A., 1976: Knife- versus abrasive-planed wood: quality of adhesive bonds. Wood and Fiber, 8 (2): 107-113.

13. Kilic, M.; Hiziroglu, S.; Burdurlu, E., 2006: Effect of machining on surface roughness of wood. Building and Environment, 41: 1074-1078.

14. Kisselbach, A., 2009: Modified timber for window construction investigations of the machinability. In: Proceedings of the $19^{\text {th }}$ International Wood Machining Seminar. H. Zhou, N. Zhu and T. Ding, eds., Nanjing, China, pp. 101-108.

15. Kvietková, M.; Gaff, M.; Gašparík, M.; Kaplan, L.; Barcík, S., 2015: Surface quality of milled birch wood after thermal treatment at various temperatures. BioResource, 10 (4): 6512-6521. https://doi.org/10.15376/biores.10.4.6512-6521.

16. Minami, T.; Nishio, S., 2015: Effect of a microtextured rake face on the cutting quality of planing applications. In: Proceedings of the $22^{\text {nd }}$ International Wood Machining Seminar. R. Hernández and C. B. Cáceres, eds., Centre de Recherche sur les Matériaux Renouvelables, Université Laval, Quebec, Canada, pp. 21-29.

17. Malkoçoğlu, A., 2007: Machining properties and surface roughness of various wood species planed in different conditions. Building and Environment, 42: 2562-2567. https://doi.org/10.1016/j.buildenv.2006.08.028.
18. Malkoçoğlu, A.; Özdemir, T., 2006: The machining properties of some hardwoods and softwoods naturally grown in Eastern Black Sea Region of Turkey. Journal of Materials Processing Technology, 173: 315-320. https://doi.org/10.1016/j.jmatprotec.2005.09.031.

19. Öhman, M.; Grubîi, V. V.; Ekevad, M., 2015: Remoistering of the wood before planing - A method for improved surface quality? In: Proceedings of the $22^{\text {nd }}$ International Wood Machining Seminar. R. Hernández and C. B. Cáceres, eds., Centre de Recherche sur les Matériaux Renouvelables, Université Laval, Quebec, Canada, pp. 245-251.

20. Sandak, J.; Tanaka, C., 2003: Evaluation of surface smoothness by laser displacement sensor 1: effect of wood species. Journal of Wood Science, 49 (4): 305-311. https://doi.org/10.1007/s10086-002-0486-6.

21. Sandak, J.; Tanaka, C.; Ohtani, T., 2004: Evaluation of surface smoothness by a laser displacement sensor II: comparison of lateral effect photodiode and multielement array. J Wood Sci, 50 (1): 22-27. https://doi:10.1007/s10086-003-0523-0.

22. Sandak, J.; Negri, M., 2005: Wood Surface Roughness What Is It? In: Proceedings of the $17^{\text {th }}$ International Wood Machining Seminar. Rosenheim, Vol. 1, pp. 242-250. www. researchgate.net/publication/267805159_Wood_surface_ roughness_- what is it (accessed on March 2, 2017).

23. Singh, A. P., Anderson, C. R., Warnes, J. M.; Matsumura, J., 2002: The effect of planing on the microscopic structure of Pinus radiata wood cells in relation to penetration of PVA glue. Holz als Roh- und Werkstoff, 60: 333-341.

24. Stewart, H. A., 1980. Some surfacing defects and problems related to wood moisture content. Wood and Fiber, 12 (3): 175-182.

25. Sensofar, 2017: http://www.sensofar.com/metrology/ sneox/ (accessed on February 27, 2017).

26. Škaljić, N.; Beljo Lučić, R.; Čavlović, A.; Obučina, M., 2009: Effect of feed speed and wood species on roughness of machined surface. Drvna industrija, 60 (4): 229-234.

27. Sofuoğlu, S. D.; Kurtoğlu, A., 2015: Effects of machining conditions on surface roughness in planing and sanding of solid wood. Drvna industrija, 66 (4): 265-272. https://doi.org/10.5552/drind.2015.1406.

28. Tersa, 2014: http://www.sfogliami.it/sfogliabili/110210/ Catalogo\%20e\%20Listino\%20Tersa_MBM_2014.pdf (accessed on March 3, 2017).

29. Tersa, 2018: http://www.tersa.swiss/products/tools (accessed on January 22, 2018).

30. Ugulino, B.; Hernández, R. E., 2016: Assessment of surface properties and solvent-borne coating performance of red oak wood produced by peripheral planning. Eur. J. Wood Prod., 75 (4): 581-593. https://doi:10.1007/s00107-016-1090-6.

31. Zhong, Z. W.; Hiziroglu, S.; Chan, C. T. M., 2013: Measurement of the surface roughness of wood based materials used in furniture manufacture. Measurement, 46: 1482-1487. https://doi.org/10.1016/j.measurement.2012.11.041.

\section{Corresponding address:}

Professor KAZIMIERZ A. ORLOWSKI, Ph.D.

Gdansk University of Technology

Faculty of Mechanical Engineering

Department of Manufacturing Engineering and Automation

G. Narutowicza 11/12

80-233 Gdansk, POLAND

e-mail: korlowsk@pg.edu.pl

ORCID id: 0000-0003-1998-521X 